\title{
Impact of Online Resources on Pre-service Teachers' Academic Performance in Social Studies Concepts
}

\author{
Thomas Ajayi ${ }^{1}$, Peter A. Amosun ${ }^{1}$, Olugbenga A. Ige ${ }^{2, *}$ \\ ${ }^{1}$ Department of Arts and Social Sciences Education, University of Ibadan, Nigeria \\ ${ }^{2}$ School of Social Sciences and Language Education, University of the Free State, Republic of South Africa
}

Received June 8, 2020; Revised September 11, 2020; Accepted September 29, 2020

\begin{abstract}
Cite This Paper in the following Citation Styles
(a): [1] Thomas Ajayi, Peter A. Amosun, Olugbenga A. Ige, "Impact of Online Resources on Pre-service Teachers' Academic Performance in Social Studies Concepts," Universal Journal of Educational Research, Vol. 8, No. 11B, pp. 5716 - 5721, 2020. DOI: 10.13189/ujer.2020.082205.
\end{abstract}

(b): Thomas Ajayi, Peter A. Amosun, Olugbenga A. Ige (2020). Impact of Online Resources on Pre-service Teachers' Academic Performance in Social Studies Concepts. Universal Journal of Educational Research, 8(11B), 5716 - 5721. DOI: 10.13189/ujer.2020.082205.

Copyright $\odot 2020$ by authors, all rights reserved. Authors agree that this article remains permanently open access under the terms of the Creative Commons Attribution License 4.0 International License

\begin{abstract}
Previous studies have established that pre-service teachers' performance in Social studies is dwindling. Prior researches have focused largely on strategies to improve students' performance in Social studies, with less attention to examining the relationship that the use of online resources have with students' performance in the subject. This study assessed the impact of online resources on pre-service teachers' academic performance in Social studies concepts. The study adopted descriptive research using correlational design, and purposive sampling technique. A total of 398 Students responded to the questionnaire. The data collected were analyzed using frequency counts, percentage, mean and standard deviation while the hypothesis was subjected to Pearson Product Moment Correlation. Findings of this study reported no significant relationship in students' use of online resources and their performance in Social Studies. This paper, therefore, concludes that, students' use of online resources has no significant relationship with their academic performance in the concepts selected in social studies. It was recommended that, adequate use of online resources by the students should be encouraged at all levels of education, to improve students' academic performance.
\end{abstract}

Keywords Social Studies, Pre-service Teachers, Online Learning, Learning Outcomes

\section{Introduction}

The mission of social studies is to inculcate in learners the life skills and values that would help them to function in a globalised society. This social science subject has the capacity to foster the ideals of nation building in pre-service teachers. Furthermore, the teaching and learning of Social studies could be enhanced using online learning resources available on the internet. It is observed that pre-service teachers' acquisition of social studies concepts in Nigerian tertiary institutions is bedeviled with many problems, particularly the dwindling performance of pre-service teachers despite their awareness of the availability of online learning materials.

Online learning resources refer to materials that are sourced and accessed electronically by users through the internet. These online resources are the major tools used by the contemporary students, researchers, and readers for learning because they can be accessed anywhere at any time. Such learning resources that are accessed online include: e-journals, e-books, online databases, electronic conference proceedings, e-magazines, e-newspapers, e-encyclopedia, CD-ROM databases, Online Public Access Catalogue $\{\mathrm{OPAC}\}$ etc. These technological resources have changed the educational practices in terms of academic learning and students' academic attainment in tertiary institutions (Akande-Alasoka, 2018; Apuke \& Iyendo, 2017). 
Another research work, "Using Technology Tools in the Public School Classroom" has revealed that both the teachers and the students' use of technology, as well as the general technological use, does not positively have any considerable influence on their academic attainment and attendance (Young, 2008). The importance and wide range of these electronic information resources for communication, information retrieval and academic and research activities are acknowledged world over. The last few decades have also seen a large amount of published materials in electronic forms. Apuke and Iyendo (2018) reported that these published materials in electronic form have attracted attention on the relevance of internet in contemporary educational contexts in developing countries. Despite the availability of these published materials, most of researches in circulation on online resources and learners' academic performance are used for general educational purposes.

In spite of the use of online resources in Social studies and their benefits, reports revealed the dwindling performance of students in the subject, which possibly could be that the aspect they understood or read failed to come out in their examination. Therefore, it requires a research like this, to examine if the use of online resources by pre-service teachers can translate to better performance in Social studies and to know the relationship between the variables of the study. The purpose of this was twofold; first, it evaluated the level of pre-service teachers' academic performance in social studies concepts. Furthermore, it ascertained the relationships in pre-service teachers' use of online resources and their attainment in selected concepts in social studies. In this research report, we gave a brief overview of the importance of social studies to pre-service teachers. Then, we critically discussed Unified Theory of Acceptance and Use of Technology (UTAUT) (Davis 1989; Venkatesh et al., 2003). Finally, we presented methods adopted to collect data from the pre-service teachers who were selected for this research and discussed the philosophical implications of the findings for pre-service teacher training. In this research, this research question was answered "What is the level of Pre-Service Teachers' performance in Social Studies concepts?" while the hypothesis "There is no significant relationship between students' use of online resources and their performance in Social Studies concepts." was tested.

\section{Theoretical Framework}

\section{The Unified Theory of Acceptance and Use of Technology (UTAUT)}

This study used the Unified Theory of Acceptance and Use of Technology (UTAUT) as a conceptual framework to help ascertain the effect of using online resources by pre-service teachers of Social Studies on their academic attainment in the course. Today, technological system has overtaken most traditional tools in the educational system world-wide. As a result, modern equipment is embraced by many academic pursuers in the educational sector. Many students have resorted to varied sources in the search for vital information to support their learning duty. Kaur and Walia (2016) stated that these trends are evident in the use of online resources such as electronic-journals, electronic books, online databases, and a host of other modern electronic resources by students to support their learning.

The internet is one of the most used technological innovations by individuals, groups, organizations and countries in the recent time of rapid technological development (Isaac et al., 2019), and technology training has become an integral part of the teacher training programmes, almost everywhere, in order to help the teachers in training acquire adequate skills to use the technology (Batane \& Ngwako, 2017; Gulbahar, 2008). Some decades back, many theoretical models were suggested for examining, and for the willingness to comprehend the usage of some of the internet technological features (Dwivedi et al., 2017; Zhou et al., 2019) while some of the old models and theories were used to clarify the doubts associated with the use of computer network (see Isaac et al., 2019). Some of these famous models which were dominant in the works of scholars like (Batane \& Ngwako, 2017; Persada \& Miraja, 2019; Jiang, et al., 2019; Dai et al., 2019), included among other models like the DeLone and McLean Information Systems success Model (DMISM), Technology Acceptance Model (TAM), the Unified Theory of Acceptance and Use of Technology (UTAUT) (Delone \& McLean 1992; Davis 1989; Venkatesh, et al., 2003). Hence, these models were vital in investigating users' technological usage (see Dwivedi et al., 2017; Isaac et al., 2019). Following the application of the aforementioned models by early studies, although, the models tendered varied explanations of information system acceptance and usage based on different perceptions (Isaac et al., 2019). Nevertheless, there was a decline in the rate of skepticisms enclosing higher internet usage.

In this study, in order to know whether pre-service teachers' internet usage and acceptance have either positively or negatively influenced their academic performance, the Unified Theory of Acceptance and Use of Technology (UTAUT) was deemed appropriate. The Unified Theory of Acceptance and Use of Technology (UTAUT) is an amalgamation of eight distinct models and theories, both theoretical concepts and framework (Jiang et al., 2019; Dai, et al., 2019; Zhou et al., 2019; Dwivedi et al., 2017; Isaac et al., 2019; Persada \& Miraja, 2019; Batane \& Ngwako, 2017).

The Unified Theory of Acceptance and Use of Technology (UTAUT) presented four outstanding constituents or factors which affect the actual system usage (Venkatesh, Morris, Davis, and Davis 2003; Batane \& Ngwako, 2017; Zhou et al., 2019). They are performance 
expectancy (perceived usefulness), effort expectancy (perceived ease of use), facilitating conditions, and social influence (see Venkatesh, Morris, Davis, and Davis (2003). Performance expectancy or perceived usefulness, according to Venkatesh, Morris, Davis, and Davis (2003), is the degree to which a person believes that using a particular system would improve his/her job output. Effort expectancy or perceived ease of use is the degree to which a person believes that using a particular system would discharge his/her effort (Venkatesh, Morris, Davis, and Davis, 2003). More so, social influence states how far a society affects a user's decision to use a particular system as perceived by the user (Venkatesh, Morris, Davis \& Davis, 2003). The fourth factor "facilitating conditions" defined the magnitude to which a person believes that there were practical and organizational structures readily accessible to support his/her internet usage (Venkatesh, Morris, Davis, and Davis, 2003).

The Unified Theory of Acceptance and Use of Technology (UTAUT) were recognized as the best or suitable theory for this discourse because they are well-grounded with the variables that influence technology adoption by an individual user. The factors listed in this theory were found to be relevant to the conditions under which pre-service teachers find themselves when they use online learning materials to support their study. Therefore, in this regard, this theory greased the understanding of why pre-service teachers used or did not use technology in the course of pursuing academic excellence.

\section{Methodology}

This study is a descriptive research using correlational design. The population of the study was made up of all 300 and 400 Levels Social Studies students of Adekunle Ajasin University Akungba, Akoko, and Adeyemi College of Education Ondo, both in Ondo State, Nigeria. The sample of this study was made up of 398 Social studies students from Adeyemi College of Education, Ondo and Adekunle Ajasin University Akungba, Akoko in Ondo State. They were purposively selected based on the criteria that they were government owned institutions where Social Studies is offered as a course of study. In each school, a total of 200 students comprising 300 and 400 level students were projected for selection. This is because the 300 and 400 level students have stayed over two years in the programme and they would have been able to take decision regarding the use of online resources. Meanwhile, it was only 198 students that completed and returned the questionnaire at
Adekunle Ajasin University, Akungba Akoko while 200 students completed the questionnaire at Adeyemi College of Education Ondo. This therefore made the total of the sample used for the study to be 398 Social Studies students. Social Studies Achievement Test (SSAT) was a self-designed instrument by the researcher to collect data from the students on their achievements in Social studies. The instrument used was validated using both face and content validity. The reliability of the instrument was carried out using Kuder- Richardson 20 reliability coefficients which gave 0.70 . The data collected were subjected to descriptive and inferential statistics. These descriptive and inferential statistics were frequency count, percentage, mean, standard deviation, and Pearson Product Moment Correlation.

\section{Results}

Research Question 1: What is the level of Pre-Service Teachers' performance in Social Studies?

Table 1. Level of Pre-Service Teachers' Performance in Social Studies

\begin{tabular}{ccccc}
\hline Score & Frequency & Percentage & Mean & $\begin{array}{c}\text { Standard } \\
\text { Deviation }\end{array}$ \\
\hline $0-29$ & 127 & 32.1 & 36.52 & 13.68 \\
\hline $30-39$ & 86 & 21.6 & & \\
\hline $40-49$ & 113 & 28.3 & & \\
\hline $50-59$ & 45 & 11.3 & & \\
\hline $\begin{array}{c}60- \\
\text { above }\end{array}$ & 27 & 6.7 & & \\
\hline Total & 398 & 100 & & \\
\hline
\end{tabular}

Highest Mark Obtainable -80

Decision Value: Low $=0.00-39.00$, Average $=40.00-59.00$, High $=$ $60.00-80.00$

Table 1 shows the level of performance of students in Social Studies. The result from the above table shows that $32.1 \%$ of the students scored between 0 and $29,21.6 \%$ scored 30-39, 28.3\% scored 40-49, 11.3\% scored 50-59 while the remaining students who constituted $6.7 \%$ scored 60 and above. The overall mean score of the students is 59.87 (a value within the range of decision value for average) with standard deviation value of 13.68. Based on this result and in line with the decision value, it can be inferred that the performance of the selected pre-service teachers in social studies is average.

Ho1: There is no significant relationship between students' use of online resources and their performance in Social Studies.

Table 2. Pearson Product Moment Correlation on Students' Use of Online Resources and their Performance in Social Studies

\begin{tabular}{llllll}
\hline Variable & N & Mean & Standard Deviation & R Remark & Sig \\
\hline Students' Use of Online Resources & & 57.4 & 10.2 & & \\
\hline & 398 & & & -.035 & Not Significant \\
\hline Students' Performance in Social Studies Concepts & & 36.4 & 13.8 & & \\
\hline
\end{tabular}


Table 2 reported no significant relationship in pre-service teachers' use of online resources and their performance in social studies $(\mathrm{N}=398 ; \mathrm{r}=-.035 ; \mathrm{p}>0.05)$. Hence, hypothesis 1 was not rejected. This result implies that uses of online resources have nothing to do with performance of students in Social Studies.

\section{Discussion}

The finding on the relationship between pre-service teachers' use of online resources and their performance in social studies indicated that students' use of online resources and their performance in Social Studies was not significant. This finding could be connected to the online resources used by the selected pre-service teachers were not the type that can translate to their performance in Social studies. Also, the findings might be related to the inability of social studies students to make use of the online resources available to them. This could also be linked to the challenges such as; lack of adequate knowledge on how to make appropriate use of online learning material like e-journals, e-books and other online related learning materials which students faced in the course of utilizing the online resources at their disposal. Another probable reason that could be responsible for the non- significant relationship between students' use of online resources and their performance in social studies could be attributed to large mass of irrelevant information used by the students which might have hindered their performance in Social studies. This finding disagrees with Jibrin et al. (2017) that affirmed that the internet has great influence on the academic performance of students in higher educational institutions. This finding is also in dissonance with the submission of Ivwighreghweta and Igere (2014) that reported a significant relationship between use of internet resources and academic performance of students in Nigerian higher educational institutions.

The non- significant relationship between students' use of online resources and their performance in social studies reported in this research could also mean that the selected pre-service teachers used these online resources for noneducational engagements. Cheng et al. (2019) mentioned the concept of online social capital. Cheng et al. (2019) defined online social capital as tangible or intangible resources which individuals obtain from their online social networks. The individuals mentioned in Cheng et al.'s (2019) research could be taken as the selected pre-service teachers in this current study. These pre-service teachers are at universities which are centre of innovative entrepreneurial ideas in Nigeria. It is a possibility that the pre-service teachers might have primarily directed their use of these online resources to accumulation of social capital other than "scholarly capital". Another important factor could be the use of these online resources by pre-service teachers for politics and public affairs which was affirmed by Muellenbach (2019) who discovered that university students used self-guided learning strategies to search for online resources, especially when they are highly interested in new information on politics and public affairs. According to Muellenbach (2019), monitorial scanning is the systematic selection of search engines to scan the news and use of online encyclopedias such as Wikipedia to locate information of interest; while opinion sampling describes the sorting of sources found on blogs and political web pages. Muellenbach (2019) described these self-guided learning strategies as monitorial scanning and opinion scanning. The use of these self-guided learning strategies by the selected pre-service teachers could have resulted in the average use of the online resources evaluated in this research for academic purposes related to their studies.

The finding with respect to Social studies students' performance indicated that pre-service teachers in Social Studies in the selected higher institutions had average performance in the course. The result of this finding could be attributed to the fact that Social studies students' attentiveness during class lecture is not enough to result into high performance in the course. It could also be that the students make intermediate consultation to other learning materials. Another reason this study could have come up in this way could be attributed to the fact that the students have an average student-lecturer relationship during class activity. This could be because the students do not make full use of their textbooks. This finding could be because of the situation whereby the students pay partial attention to reading their textbooks. It could be that the students do not take their continuous assessment tests seriously or they do not jot down some of the important points, during class lecture. It could also be that the aspect they understand or read failed to come out in their examination. This finding corroborates the finding of Gbollie and Keamu (2017) whose finding showed that students' performance is moderate.

\section{Conclusions}

The use of online resources to improve academic performance of pre-service teachers in social studies is very pertinent in the current globalized educational systems. Nevertheless, it could be concluded based on the finding of this study that the pre-service teachers' relationship with the use of online resources in social studies had no significant relationship with their performance, while the pre-service teachers' performance in the subject is average. The outcomes of this research have opened new locus of educational research in the training of pre-service teachers. It was evident from the outcome of this study and previous research that pre-service teachers do not solely use online resources to accumulate "scholarly capital". It is therefore 
recommended that teacher training institutions should devise philosophical strategies to teach pre-service teachers on the benefits of using diverse online resources for educational purposes. It is our opinion that such philosophical use of online learning materials would improve their performance of pre-service teachers in teacher training programmes.

\section{REFERENCES}

[1] Akande-Alasoka, K.E. (2018). Communication technology and governance: The case of Nigeria. Faculty of Business, University of Plymouth. http://hdl.handle.net/10026.1/1194 3

[2] Apuke, O.D., \& Iyendo, T.O. (2017). Two sides of a coin: revisiting the impact of social networking sites on students' performance in selected higher educational settings in Nigeria. Sci. Int., 29(6), 1265-1275.

[3] Alharbi, S. T. (2014). Trust and acceptance of cloud computing: A revised UTAUT model. In 2014 International Conference on Computational Science and Computational Intelligence, pp. 131-134. https//doi.org/10. 1109/CSCI.2014.107.

[4] Amosun, P.A. \& Ige, O.A. (2009). Internet Crime: A New Breed of Crime among In-school Aged Children in Nigeria. The African Symposium: An Online Journal of African Educational Research Network, 9(20), 90-98.

[5] Batane, T., \& Nwakwo, A. (2017). Technology use by pre-service teachers during teaching practice: Are new teachers embracing technology right away in their first teaching experience? Australasian Journal of Educational Technology, 33(1), 48-61. https://doi.org/10.14742/ajet.229 9

[6] Cheng, C., Wang, H., Sigerson, L. \& Chau, C. (2019). Do the Socially Rich Get Richer? A Nuanced Perspective on Social Network Site Use and Online Social Capital Accrual. Psychological Bulletin, 145(7), 734-764 http://dx.doi.org/1 $0.1037 /$ bul0000198.

[7] Dai, B., Larnyo, E., Tetteh, E. A., Aboagye, A. K., \& Musah, A. I. (2019). Factors Affecting Caregivers' Acceptance of the Use of Wearable Devices by Patients with Dementia: An Extension of the Unified Theory of Acceptance and Use of Technology Model. American Journal of Alzheimer's disease and Other Dementias, 35, 1-11. https://doi.org/10.1 $177 / 1533317519883493$.

[8] Davis, F.D., (1989). Perceived usefulness, perceived ease of use, and user acceptance of information technology. MIS Quarterly, 13, 319-340.

[9] DeLone, W. H., \& McLean, E.R. (1992). Information system: The quest for the dependent variable. Information System Research, 3(1), 60-95.

[10] DeLone, W. H., \& McLean, E.R. (2003). The DeLone and McLean model of information systems success: A ten year update. Journal of Management Information Systems, 19,
9-31.

[11] Dwivedi, Y. K., Rana, N. P., Jeyara, A., Clement, M., \& Williams, M. D. (2017). Re-examining the Unified Theory of Acceptance and Use of Technology (UTAUT): Towards a Revised Theoretical Model. InfSyst Front 21, 719-734. https://doi.org/10.1007/s10796-017-9774-y.

[12] Gbollie, C., \& Keamu, H.P. (2017). Student academic performance: The role of motivation, strategies, and perceived factors hindering Liberian junior and senior high school students learning. Education Research International, https://doi.org/10.1155/2017/1789084

[13] Goodhue, Dale, L., \& Thompson, R. L. (1995). Task-technology fit and individual performance MIS Quarterly, 19(2), 213-236.

[14] Gülbahar, Y. (2008). ICT usage in higher education: A case study on pre-service teachers and instructors. The Turkish Online Journal of Educational Technology, 7(1), 32-37. http://www.tojet.net/articles/v7i1/713.pdf

[15] Ifinedo, P. (2017). Examining students' intention to continue using blogs for learning: Perspectives from technology acceptance, motivational, and social-cognitive frameworks. Comput Hum. Behav. 72, 189-199.

[16] Ivwighreghweta, O., \& Igere, M.A., (2014). Impact of the internet on academic performance of students in tertiary institutions in Nigeria. Inf. Impact J. Inf. Knowl. Manag, 5(2), 47-56.

[17] Isaac, O., Abdullah, Z., Aldholay, A. H., \& Ameen, A. A. (2019). Antecedents and Outcomes of internet Usage within Organizations in Yemen: An extension of the Unified Theory of Acceptance and Use of Technology (UTAUT) Model. Asia Pacific Management Review, 24 (7019), 335-354.

[18] Jiang, S., Liu, X., Liu, N., \& Xiang, F. (2019). Online life insurance purchasing intention: Applying the unified theory of acceptance and use of technology. Social Behavior and Personality: An international journal, 47(7), e8141. https://doi.org/10.2224/sbp.8141.

[19] Jibrin. M.A., Musa. M.N., \& Shittu. T. (2017). Effects of internet on the academic performance of tertiary institutions' students in Niger state, Nigeria. International Journal of Education, Learning and Training, 2(2), 57-69.

[20] Persada, S. F., \& Miraja, B. A. (2019). Understanding the Generation Z Behavior on D-Learning: A Unified Theory of Acceptance and Use of Technology (UTAUT) Approach. http://doi.org/10.3991/ijet.v14i05.9993.

[21] Venkatesh, V., Morris, M.G., Davis, G.B., \& Davis, F.D., (2003). User Acceptance of Information Technology: Towards a Unified View. MIS Quarterly, 27(3), 425-478.

[22] Young. R. (2008). Using technology tools in the public school classroom. Unpublished Master of Science Thesis, The Graduate School, University of Wiscousin-Stout, Menomonie, WI.

[23] Zhou, L. L., Owusu-Marfo, J., Antwi, H. A., Antwi, M. O., Kachie, A. D. T., \& Ampon-Wireko, S. (2019). "Assessment of the social influence and facilitating conditions that support nurses' adoption of hospital electronic information 
management systems (HEIMS) in Ghana using the unified theory of acceptance and use of technology (UTAUT) model"
Medical Informatics and Decision https://doi.org/10.1186/s12911-019-0956-z.
Making. 